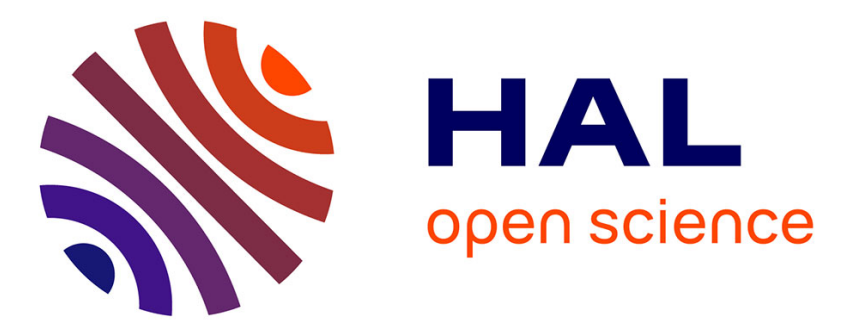

\title{
Chemical and electrochemical oxidation of aqueous solutions of NADH and model compounds
}

Philippe Leduc, Daniel R. Thevenot

\section{To cite this version:}

Philippe Leduc, Daniel R. Thevenot. Chemical and electrochemical oxidation of aqueous solutions of NADH and model compounds. Bioelectrochemistry and Bioenergetics, 1974, 1, pp.96-107. 10.1016/0302-4598(74)85011-7 . hal-01179276

\section{HAL Id: hal-01179276 \\ https://hal.science/hal-01179276}

Submitted on 23 Jul 2015

HAL is a multi-disciplinary open access archive for the deposit and dissemination of scientific research documents, whether they are published or not. The documents may come from teaching and research institutions in France or abroad, or from public or private research centers.
L'archive ouverte pluridisciplinaire HAL, est destinée au dépôt et à la diffusion de documents scientifiques de niveau recherche, publiés ou non, émanant des établissements d'enseignement et de recherche français ou étrangers, des laboratoires publics ou privés. 


\title{
Chemical and Electrochemical Oxidation of Aqueous Solutions of NADH and Model Compounds *
}

\author{
by P. Leduc and D. Thévenot
}

Laboratoire d'Energétique Biochimique, Université Paris Val de Marne, Avenue du Général de Gaulle, 940oo - Créteil (France)

\section{Summary}

Aqueous solutions of NADH and of model compounds such as I4, dihydro- $\mathrm{N}_{1}$-propyl- and $\mathrm{I}-4$, dihydro- $\mathrm{N}_{1}$-benzyl-nicotinamide are oxidized on rotating $\mathrm{Pt}$ disk electrode at $+0.66 \pm 0.02 \mathrm{~V}$ (N.H.E.). This two-electron wave is $\mathrm{pH}$ independent in the range of 7-I3. Both macroelectrolysis on $\mathrm{Pt}$ at $+0.85 \mathrm{~V}$ (N.H.E.) and chemical oxidation by $\left[\mathrm{Fe}\left(\mathrm{CN}_{6}\right]^{3-}\right.$ lead to $\mathrm{NAD}+$ or model compounds.

Differences between biochemical, chemical and electrochemical oxidation of $\mathrm{NADH}$ are discussed, especially in terms of energetics and mechanisms of reactions.

\section{Introduction}

It is now well known that the nicotinamide adenine dinucleotide $\left(\mathrm{NAD}^{+}\right)$-dihydronicotinamide adenine dinucleotide (NADH) system plays a prominent part in the biological oxidation-reduction reactions. It participates in a large number of metabolic pathways as well as in the respiratory chain. However, the mechanism of these reactions has not yet been elucidated, even in the absence of pyridine nucleotide dependent enzymes.

In order to simplify the study of their redox properties $\mathrm{NAD}^{+}$ and NADH have been commonly replaced by model compounds in which a simple alkyl group takes the place of the ribose-pyrophosphate-adenine moiety : their redox and spectrophotometric characteristics are very similar to the NAD+-NADH ones.

Extensive works have been published on the reduction of pyridine nucleotides (mainly NAD+) and of model compounds (mainly $\mathrm{N}_{1}$-methyl nicotinamide salts) ${ }^{1-7}$ but the oxidation of NADH and its analogs has given rise to still few and partial studies. ${ }^{8}$ In unbuffered acetonitrile

* Presented at the 2nd International Symposium on Bioelectrochemistry, Pont à Mousson, I-5 Oct. I973 
HAAS ${ }^{\text {9-10 }}$ reported a one electron oxidation leading to NAD+ or model compound by macroscale electrolysis. In $\mathrm{pH} 8.6$ aqueous solutions of $\mathrm{NADH}$ he obtained ${ }^{10}$ an oxidation wave on rotating Pt electrode $\left[\left(U_{1 / 2}=\right.\right.$ $=0.90 \pm 0.02 \mathrm{~V}$ (N.H.E.) $]$ and on rotating carbon electrode $\left[U_{1 / 2}=\right.$ $=+0.67 \pm 0.03 \mathrm{~V}(\mathrm{~N} . \mathrm{H} . \mathrm{E})$.$] leading to NAD + by a two electron mac-$ roscale electrolysis. The $\mathrm{pH}$ range of these studies was not large enough to bring useful information on the mechanism energetics of the electron and proton transfer.

Furthermore attention should be paid for the " primary acid modification" of aqueous NADH or models solutions: at $\mathrm{pH}$ below 7 the 5,6 double bond of I,4 dihydronicotinamides is saturated, the UV absorption band is shifted from 355 to $290-300 \mathrm{~nm}$ and the chemical oxidation of the new compound is more difficult. ${ }^{11-22}$

Being aware of the possible spontaneous reactions of $\mathrm{NADH}$ and models in aqueous buffered solutions, we have determined the principal electrochemical features of these compounds and followed their complete oxidation both by macroscale electrolysis and by chemical reaction.

\section{Experimental}

\section{Reagents}

NADH was obtained by "MANN" (from NAD+ $90 \%$ reduced). All other products were prepared in our laboratory :

$\mathrm{NMeN}+\mathrm{I}^{-}$according to HoLMAN and WIEGAND ${ }^{23}$ (M.P. : 2 II $^{\circ} \mathrm{C}$, reported $204^{\circ} \mathrm{C}$, "SIGMA" and " $\mathrm{K}$ and $\mathrm{K}$ " reagents : $\left.2 \mathrm{IO}^{\circ}-2 \mathrm{II}^{\circ} \mathrm{C}\right)$,

$\mathrm{NBzN}+\mathrm{Cl}^{-}$according to $\mathrm{KIM}$ and $\mathrm{CHAYKIN}^{20}$ (M.P.: $245^{\circ} \mathrm{C}$, reported 24I $\left.{ }^{\circ} \mathrm{C}\right)$,

NPrN ${ }^{+} \mathrm{Br}^{-}$according to ANDERSON and BERKELHAMMER ${ }^{12}$ (M.P.: I70$\mathrm{I} 75^{\circ} \mathrm{C}$ reported $\left.\mathrm{I} 68-\mathrm{I} 72^{\circ} \mathrm{C}\right)$,

NMeNH was prepared by the procedure given by KARRER ${ }^{11}$ as modified by $\mathrm{HAAS}^{10}$ (M.P. : $84^{\circ} \mathrm{C}$, reported $84-85^{\circ} \mathrm{C}$ ). Stored in a freezer at $-20{ }^{\circ} \mathrm{C}$ with $\mathrm{P}_{2} \mathrm{O}_{5}$, it nevertheless decomposed to a red, viscous residue and could not be recovered by any recrystallization,

NPrNH was prepared according to Suelter and Metzler ${ }^{24}$ (M.P.: $92^{\circ} \mathrm{C}$, reported $\left.86^{-}-96^{\circ} \mathrm{C}\right)$,

NBzNH according to ANDERson and Berkelhammer ${ }^{12}$ (M.P.: I23 ${ }^{\circ} \mathrm{C}$ dec., reported $120^{\circ} \mathrm{C}$ ).

The last three dithionite reductions were performed in a glove bag with permanent $\mathrm{N}_{2}$ circulation; all reaction, extraction or recrystallization solvents were previously deoxigenated by a $\mathrm{N}_{2}$ stream.

Buffer solutions were prepared from chemicals of analytical reagent grade, at a concentration Ioo or 200 time greater than those of examined compound (usually o.I $M$ acidic and basic form). 


\section{Control of purity. Determination of concentration}

We checked all our aqueous solutions with a Cary I4 recording spectrophotometer and a pair of five millimeters silica cells.

With freshly prepared solutions of our products we found the following $\varepsilon_{\max }$ and $\lambda_{\max }: \varepsilon_{\max }=7250 \pm 50$ for $\mathrm{NBzNH} ; \varepsilon_{\max }=7$ I00 \pm 50 for $\mathrm{NPrNH}$ at $\lambda_{\max }=355 \mathrm{~nm}, \varepsilon_{\max }=3950 \pm 50$ for $\mathrm{NBzN}+\mathrm{Cl}^{-}$and $\mathrm{NPrN}+\mathrm{Br}^{-}$at $\lambda_{\max }=265 \mathrm{~nm}$. These values are in good agreement with those previously reported. Therefore, all concentrations of freshly prepared solutions were given with an error range of $2 \%$.

\section{Apparatus}

For voltammetry and polarography a conventional three electrodes cell of $20 \mathrm{~cm}^{3}$, thermostated at $25.0 \pm 0 .{ }^{\circ} \mathrm{C}$ was employed.

Although the potential are given vs. N.H.E. all measurements were made with $\mathrm{Ag}|\mathrm{AgCl}| \mathrm{KCl}$ sat. reference electrodes, which potentials were frequently controlled $v s$. a saturated calomel electrode.

For drop-time controlled polarography we used a $30 \mathrm{~cm}$ capillary with a mercury height of $50 \mathrm{~cm}$; the free drop-time was $8.2 \mathrm{~s}$ and the mercury flow rate $0.85 \mathrm{mg} / \mathrm{s}$; the drop-time was controlled by a TACUSSEL electrical hammer (M.P.O. animated by a G.C.M.R.) and regulated at $0.5 \mathrm{~s}$.

The working electrodes used in voltammetry were disks of $\mathrm{I} .0 \mathrm{~mm}$ diameter of Pt, Au and glassy carbon.

Polarography and voltammetry were carried out with different TAcussel apparatuses (PRT 500 LC, Servovit 9 B, S6 RZ millivoltmeter) and a SEFRAM XY Luxytrace bigalvanometric recorder.

For coulometry, a TACUSSEL IG 4-IIOO electronic integrator was used, checked by a current recorder Sefram-Graphispot. During the beginning of macroelectrolysis a FonTAINe A-6o V power supply was placed between the counter electrode and the generator.

\section{Procedure}

Test solutions of $\mathrm{NBzN}+\mathrm{Cl}^{-}$and $\mathrm{NPrN}+\mathrm{Br}^{-}$were prepared by adding small quantities of highly concentrated solutions to known volume of deoxygenated buffer; because of the weaker solubility of $\mathrm{NBzNH}$ and $\mathrm{NPrNH}$ the solutions were directly prepared in the buffer and then deoxygenated.

The disk electrodes for voltammetry were mechanically treated by successive polishings using emery papers. The glassy carbon electrode was, according to HAAS ${ }^{10}$ dipped during $30 \mathrm{~s}$ in concentrated $\mathrm{H}_{2} \mathrm{SO}_{4}$. The rotation speed was Iooo r.p.m. for all measurements.

The sweep rate was $0.120 \mathrm{~V} / \mathrm{min}$ for voltanmetry and $0.250 \mathrm{~V} / \mathrm{min}$ for d.c. polarography. 


\section{Electrochemical properties of NADH and model compounds in aqueous solution}

The size of NADH molecule and the nature of the ribose-pyrophosphate-adenine side chain on the pyridine ring have two consequences: first, a rather small mobility and consequently weak diffusion currents second, some adsorption reactions which are likely to make difficult the determination of the electrochemical properties of the compound under investigation.

Therefore in this study we have mostly used model compounds of $\mathrm{NADH}$, namely the $\mathrm{I}-4$, dihydro- $\mathrm{N}_{1}$-benzylnicotinamide $(\mathrm{NBzNH})$ and the I-4, dihydro- $\mathrm{N}_{1}$-propyl nicotinamide (NPrNH).

\section{Electrochemical properties of the $\mathrm{NBzNH}$}

The NBzNH molecule is oxidizable at a rotating $\mathrm{Pt}$ disk electrode; the current--potential curve corresponding to buffered aqueous solutions, containing $5 \times \mathrm{IO}^{-4} \mathrm{M}$ of $\mathrm{NBzNH}$, is reproducible within $\pm 20 \mathrm{mV}$ fluctuation, whatever is the mechanical or chemical treatment of the electrode surface.

We registered different curves by anodic and cathodic potential scan in the range from +0.2 up to +I.2 V (N.H.E.) ; the two corresponding $U_{1 / 2}$ values differ by about $30 \mathrm{mV}$. Thus all given $U_{1 / 2}$ values refer to anodic potential sweep.

\section{Influences of $p H$ variations}

Checking the solutions by UV spectrophotometry we observed that $\mathrm{NBzNH}$ is reasonably stable when the $\mathrm{pH}$ ranges from 7.0 to 13.0 in aqueous buffered solutions.

Within these limits, we registered a single $\mathrm{pH}$ independent oxydation wave, corresponding to $U_{1 / 2}=+0.66 \pm 0.02 \mathrm{~V}$ (N.H.E.) and $I_{d}=$ $=+5.8 \pm 0.2 \mu \mathrm{A} \mathrm{m} M^{-1}$.

The slope of this wave is rather weak, $U_{3 / 4}-U_{1 / 4}=90 \pm 7 \mathrm{mV}$, and corresponds to an irreversible process.

\section{Influence of the $N B z N H$ concentration}

The observed anodic wave shows an amplitude proportional to the $\mathrm{NBzNH}$ concentration between $3 \times \mathrm{IO}^{-5}$ and $5 \times \mathrm{IO}^{-4} M$; the half-wave potential does not significantly depend upon the concentration.

\section{Determination of the number of exchanged electrons}

We recorded, within the same experimental conditions, the currentpotential curves for solutions of known compounds, namely ferricyanide, hydroquinone and I-4 dihydroxyanthraquinone (Table I). All these 
molecules are roughly of the same size as $\mathrm{NBzNH}$; so if one compares their limiting diffusion current with that measured for $\mathrm{NBzNH}$, one can deduce that two electrons are involved in the voltammetric oxidation process of $\mathrm{NBzNH}$.

Table I. Comparison of diffusion currents obtained by voltammetry on the same rotating $\mathrm{Pt}$ disk electrode.

\begin{tabular}{|c|c|c|c|}
\hline Products & $\begin{array}{l}\text { Molecular } \\
\text { weight }\end{array}$ & $\begin{array}{l}\text { Number of } \\
\text { electron } \\
\text { exchanged }\end{array}$ & $\begin{array}{c}I_{d} / c \\
\mu A / \mathrm{m} M\end{array}$ \\
\hline$\left[\mathrm{Fe}(\mathrm{CN})_{6}\right]^{3-}$ & 329 & I & $2.5 \pm 0.1$ \\
\hline$p$-hydroquinone & I IO & 2 & $6.2 \pm 0.3$ \\
\hline I-4, dihydroxyanthraquinone & 240 & 4 & $12.2 \pm 0.6$ \\
\hline $\mathrm{NPrNH}$ & I66 & & $6.2 \pm 0.2$ \\
\hline $\mathrm{NBzNH}$ & $2 \mathrm{I}_{4}$ & & $5.8 \pm 0.1$ \\
\hline $\mathrm{NADH}$ & 664 & & $0.6 \pm 0.1$ \\
\hline
\end{tabular}

\section{Influence of the rotation speed and of the material of the electrode}

The anodic wave observed with a rotating Pt disk shows an amplitude proportional to the square root of the electrode rotation speed (between 200 and 2000 r.p.m.) ; the potential does not depend on this parameter. In order to check the possible influence of electrode material, we compared the current-potential curves registered for the same $\mathrm{NBzNH}$ solution $\left(5 \times \mathrm{IO}^{-4} M\right)$, at $\mathrm{pH} 8.2$, with different disk electrodes, made of $\mathrm{Pt}, \mathrm{Au}$ and glassy carbon. We obtained :

$$
\begin{array}{lll}
\text { with Pt: } & U_{1 / 2}=0.66 \pm 0.02 \mathrm{~V}(\mathrm{~N} . \mathrm{H} . \mathrm{E} .) ; & U_{3 / 4}-U_{1 / 4}=90 \pm 7 \mathrm{mV} \\
\text { with } \mathrm{Au}: & U_{1 / 2}=0.60 \pm 0.025 \mathrm{~V} \text { (N.H.E.) } ; U_{3 / 4}-U_{1 / 4}=100 \pm \text { Io } \mathrm{mV} \\
\text { with } \mathrm{C}: & U_{1 / 2}=0.48 \pm 0.04 \mathrm{~V} \text { (N.H.E.) } ; U_{3 / 4}-U_{1 / 4}=120 \pm 10 \mathrm{mV}
\end{array}
$$

These results indicate that the nature of the electrode material does not alter the shape of the irreversible oxidation wave but influences significantly its half-wave potential.

\section{Electrochemical properties at $p H$ lower than 7}

At $\mathrm{pH}$ below 7 the $\mathrm{NBzNH}$ molecule is spontaneously altered by saturation of the 5.6 bond in the pyridine ring. 
This chemical reaction results on the one hand in a modification of the UV absorption spectrum: the absorption peak at $365 \mathrm{~nm}$ is replaced by another, located between 290 and $300 \mathrm{~nm}$; on the other hand, the redox properties of the solution are changed (Fig. I) : the reaction product shows at the rotating $\mathrm{Pt}$ disk electrode a single $\mathrm{pH}$-independent anodic wave with $U_{1 / 2}=1.075 \pm 0.0 I \mathrm{~V}$ (N.H.E.) in the $4.6-7.0 \mathrm{pH}$ range.

Comparison between the electrochemical properties of NADH and of its model compounds in aqueous solutions

With a rotating Pt disk electrode we registered an anodic wave in aqueous solutions of $\mathrm{NADH}$ and $\mathrm{NPrNH}$.

$\mathrm{NPrNH}$ presents as model compound of $\mathrm{NADH}$ an important disadvantage; it evolves in solution still more rapidly than $\mathrm{NBzNH}$ :

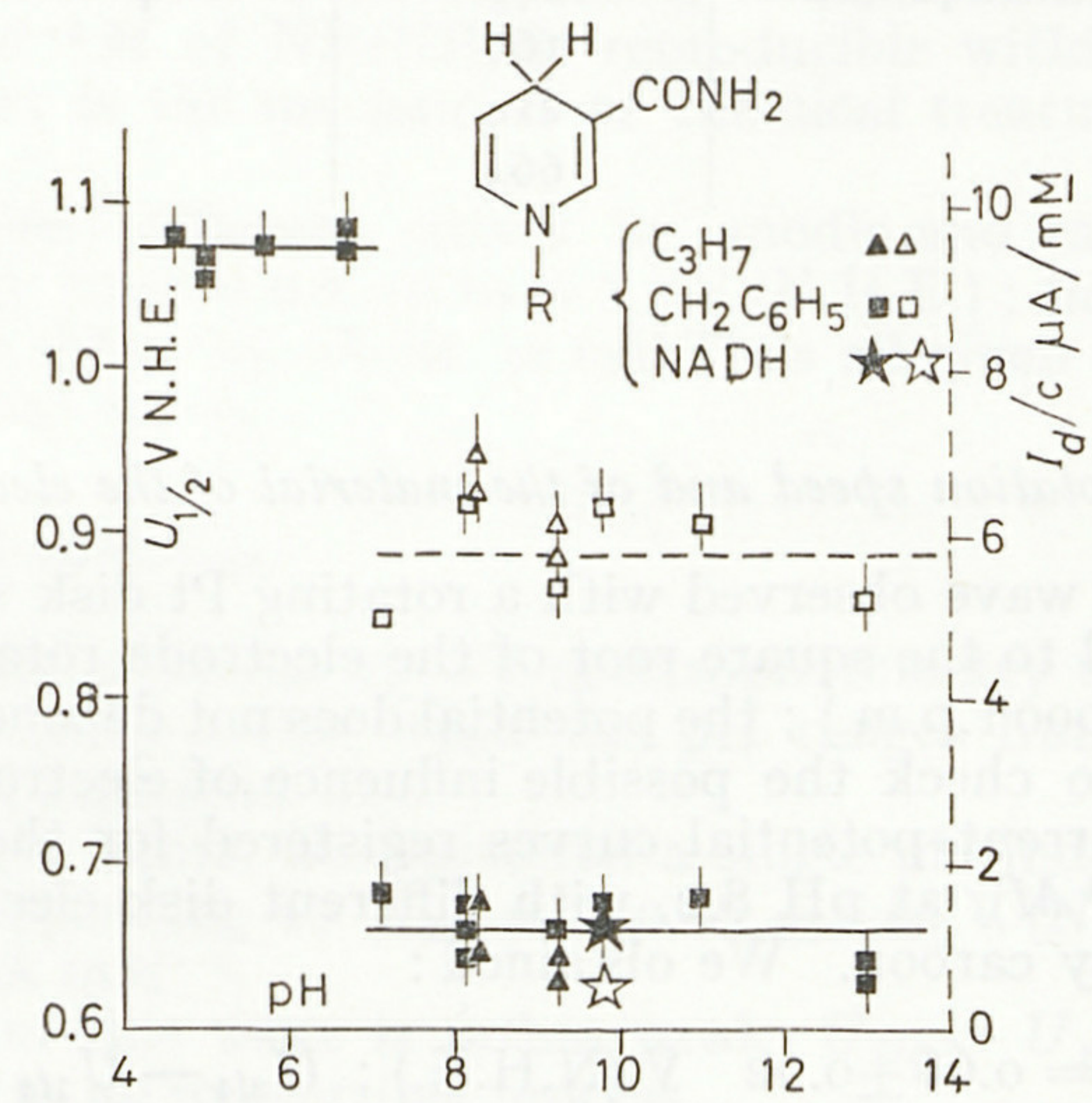

Fig. I.

Diagram $U_{1 / 2} v s . \mathrm{pH}$ and $I_{d} / c v s$. $\mathrm{pH}$ for the oxidation of $5 \times 10^{-4} M$ aqueous solutions of $\mathrm{I}-4$, dihydro, $\mathrm{N}_{1}$-propyl-nicotinamide $\left(\mathrm{R}=\mathrm{C}_{3} \mathrm{H}_{7}\right)$, I-4, dihydro, $\mathrm{N}_{1}$-benzyl-nicotinamide $\left(\mathrm{R}=\mathrm{CH}_{2} \mathrm{C}_{6} \mathrm{H}_{5}\right)$ and $\mathrm{NADH}$ on rotating $\mathrm{Pt}$ disk electrode.

so it is still more necessary to use freshly prepared solutions and to check their UV spectrum during the voltammetric recordings. The current potential curves registered for $5 \times \mathrm{IO}^{-4} M \mathrm{NPrNH}$ solutions, at $\mathrm{pH} 8.2$ and 9.2, show half-wave potentials, slopes and limiting diffusion currents which are equal to the above mentioned results for similar NBzNH solutions (Fig. I and Table I). 
For the purpose of comparison, we performed a measurement with a Io $^{-3} M$ NADH solution at $\mathrm{pH} 9.5$ on a rotating $\mathrm{Pt}$ disk electrode; the corresponding anodic wave shows an equal potential to that observed for $\mathrm{NBzNH}$ and NPrNH (Fig. I). However, the diffusion current reaches a limiting value about ten times weaker (Table I). Furthermore no distinct wave can be observed for a return potential sweep or later anodiccathodic sweeps, unless the electrode surface has been mechanically repolished. The electrochemical oxidation reaction of NADH is thus partially perturbed or hidden by some surface reaction, probably an adsorption one.

\section{Total oxidation of 1-4dihydro $\mathbf{N}_{1}$-benzyldihydronicotinamide}

In order to elucidate the mechanism of the reaction $\mathrm{NADH} \rightarrow \mathrm{NAD}+$, we made several total oxidations of NBzNH, which is stable enough in the $7-\mathrm{I} 3 \mathrm{pH}$ range. For unambiguously identifying the formation of $\mathrm{N}_{1}$-benzylnicotinamide $(\mathrm{NBzN}+)$, we measured the electrochemical characteristics of $\mathrm{NBzN}+\mathrm{Cl}^{-}$and registered its $\mathrm{UV}$ spectrophotometric data.

\section{Polarographic reduction of aqueous buffered solutions of $\mathrm{NBzN}+\mathrm{Cl}^{-}$}

We registered current potential curves obtained by drop-time controlled polarography of $\mathrm{IO}^{-4} M \mathrm{NBzN}+\mathrm{Cl}^{-}$aqueous solutions. The first reduction wave is $\mathrm{pH}$-independent over the investigated $\mathrm{pH}$ range (4.6 to Io.9); it corresponds to the potential $U_{1 / 2}=-0.635 \pm 0.0 \mathrm{I}$ $\mathrm{V}$ (N.H.E.) and so it appears at significantly higher potential values than the first polarographic reduction wave of the $\mathrm{N}_{1}$-methyl and $\mathrm{N}_{1}$-propylnicotinamide salts at the same concentration (Fig. 2 and ref. [4] and [6]), $U_{1 / 2}=-0.83 \pm 0.03 \mathrm{~V}$ (N.H.E.). We obtained limiting diffusion current values with $\mathrm{IO}^{-4} M$ solutions which are about $30 \%$ smaller in the case of $\mathrm{NBzN}+\mathrm{Cl}^{-}$and $\mathrm{NPrN}+\mathrm{Br}^{-}$than for solutions of $\mathrm{NMeN}+\mathrm{I}^{-}$with the same concentration.

A second wave emerges at $\mathrm{pH}$ higher than 8 from the background discharge ; the half-wave potential seems to be independent of the alkyl group of the pyridine ring; except for a value obtained with $\mathrm{NBzN}+$ in a butylamine buffer at pH I0.9 (Fig. 2).

As for the reduction of $\mathrm{NMeN}+\mathrm{I}^{-}$, limiting currents of both waves are proportional to $\mathrm{N}_{1}$-alkyl-nicotinamide salt concentration and an increase of this concentration leads to potential shifts: $U_{1 / 2}$ of the first reduction wave shifts toward less negative potentials, whereas $U_{1 / 2}$ of the second wave shifts toward more negative potentials.

In addition to this general scheme $\mathrm{NBzN}+\mathrm{Cl}$ - first reduction wave splits progressively when its concentration rises above approximatly a $3 \times \mathrm{IO}^{-4} M$ level. As for the second pyrimidine reduction wave in the 


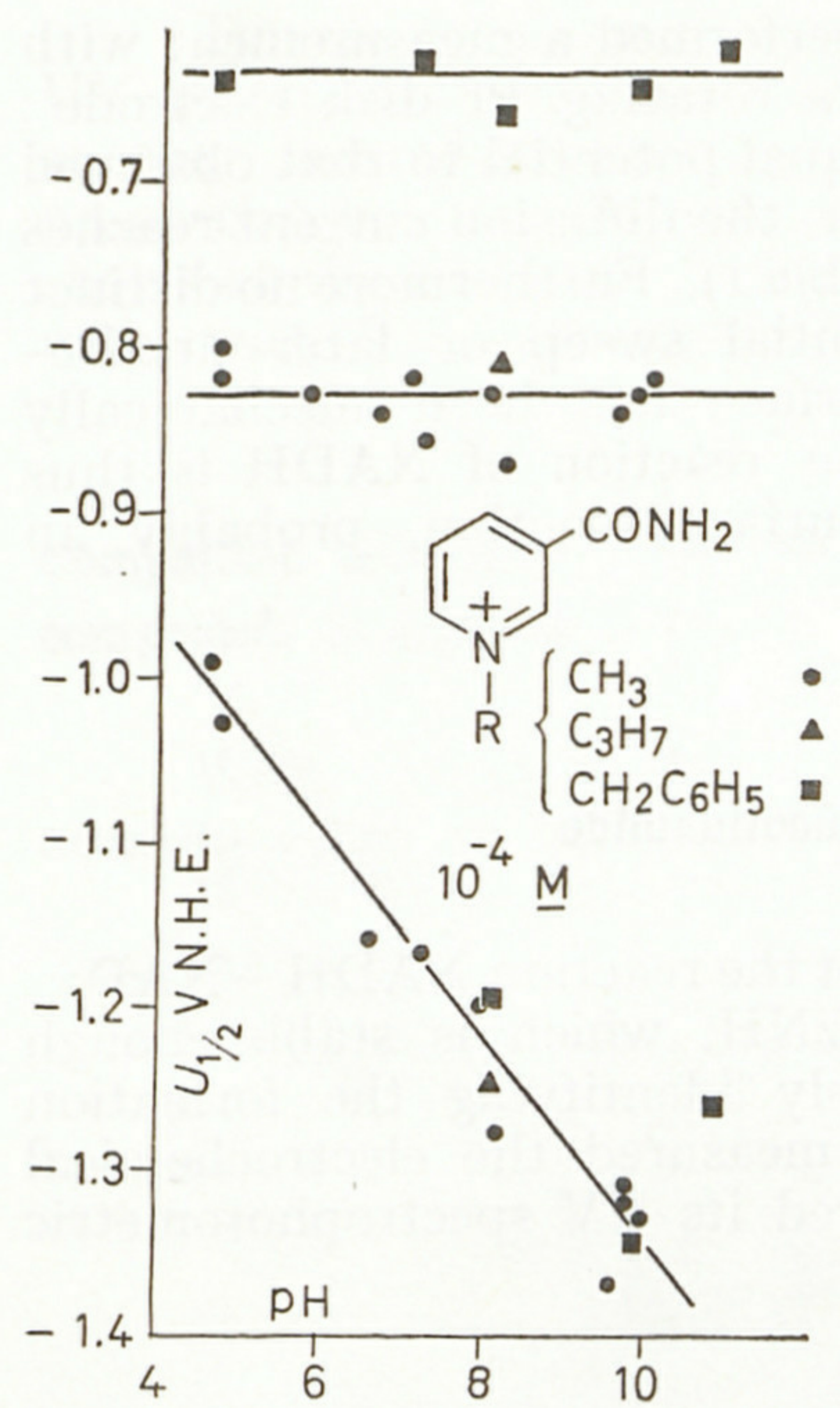

3.0-5.2 pH range, when such a phenomenon was observed and studied in details ${ }^{25}, 26$ the height of the first split wave is concentration-independent whereas the height of the sum of the two split waves is proportional to the concentration.

Fig. 2.

Diagram $U_{1 / 2}$ vs. $\mathrm{pH}$ for the reduction of $\mathrm{IO}^{-4}$ $M$ aqueous solutions of $\mathrm{N}_{1}$-methyl-nicotinamide iodide $\left(\mathrm{R}=\mathrm{CH}_{3}\right) \quad \mathrm{N}_{1}$-propylnicotinamide-bromide $\left(\mathrm{R}=\mathrm{C}_{3} \mathrm{H}_{7}\right)$ and $\mathrm{N}_{1}$-benzylnicotinamide chloride $\left(\mathrm{R}=\mathrm{CH}_{2} \mathrm{C}_{6} \mathrm{H}_{5}\right)$ by drop-time controlled polaro graphy.

\section{Macroelectrolysis of aqueous buffered solutions of $\mathrm{NBzNH}$}

Seven different macroelectrolyses on $\mathrm{Pt}$ gauze were conducted in $5 \times \mathrm{IO}^{-4} M \mathrm{NBzNH}$ aqueous solutions, buffered at $\mathrm{pH}$ 8.2. The potential was controlled at $+0.850 \pm 0.05 \mathrm{~V}$ (N.H.E.). Analysis of the product of these electrolyses was performed through UV spectrophotometry and drop-time controlled polarography (Fig. 3 and 4). Results indicate clearly that the electrolysis product is $\mathrm{NBzN}+$. The quantity of removed $\mathrm{NBzNH}$ is equal to the quantity of formed $\mathrm{NBzN}+$ and both quantities are proportional to the number of integrated coulombs. In spite of numerous attempts to have reproducible results and to clean thoroughly the $\mathrm{Pt}$ gauze, $n$ values were scattered between I.2 and I.9 F/mol, the mean and more frequent value being I. $55 \mathrm{~F} / \mathrm{mol}$.

As shown on curve I of Fig. 4 the initial $\mathrm{NBzNH}$ solution presents a small polarographic reduction wave. It was observed in borate, Tris and glycinate buffers ( $\mathrm{pH} 8.2$ and 9.8) at $U_{1 / 2}=-$ r.09 $\pm 0.03 \mathrm{~V}$ (N.H.E.). Its height in $5 \times \mathrm{IO}^{-4} M \mathrm{NBzNH}$ solution is in the ratio $\mathrm{I}$ to 5 with $5 \times 10^{-4} M \mathrm{NBzN}+$ wave height. As NBzNH contains less than $2 \%$ impurity (checked by its UV spectrum), this polarographic wave cannot be related to a foulness resulting from the synthesis of this compound. 
Fig. 3.

U.V. spectra of a $5 \times \mathrm{IO}^{-4} M \mathrm{I}-4$, dihydro- $\mathrm{N}_{1}$-benzylnicotinamide aqueous solution (buffered at $\mathrm{pH}$ 8.3) during a macroscale electrolysis at $+0.85 \mathrm{~V}$ (N.H.E.). Initial solution : curve (I), solution after 0.25 (2), 0.50 (3), I.O (4) and I.2 F/mole (5) electrolysis. $5 \times \mathrm{IO}^{-4} \mathrm{M} \mathrm{NBzN}+\mathrm{Cl}^{-}$aqueous solution in the same buffer (-- - ).

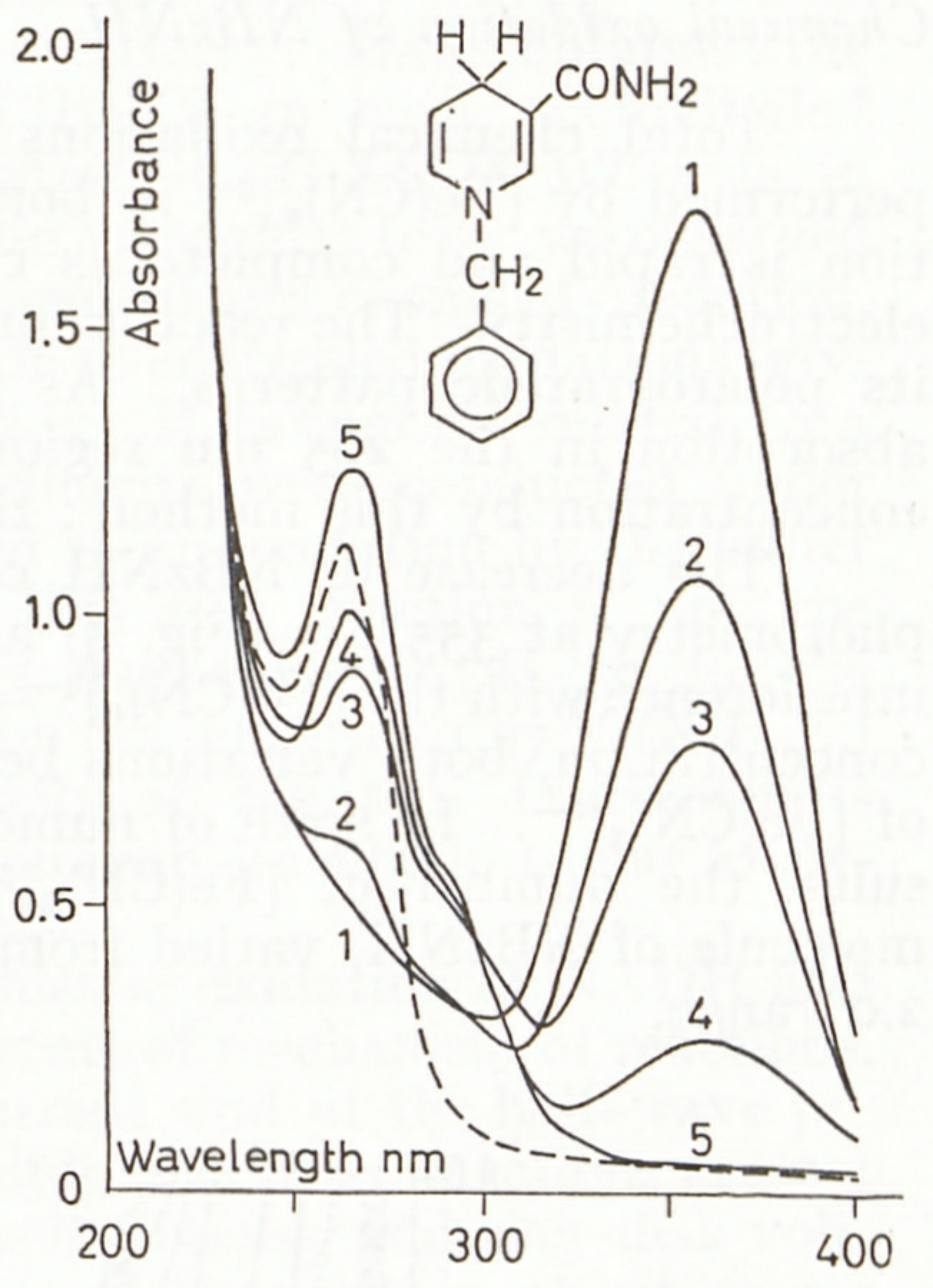

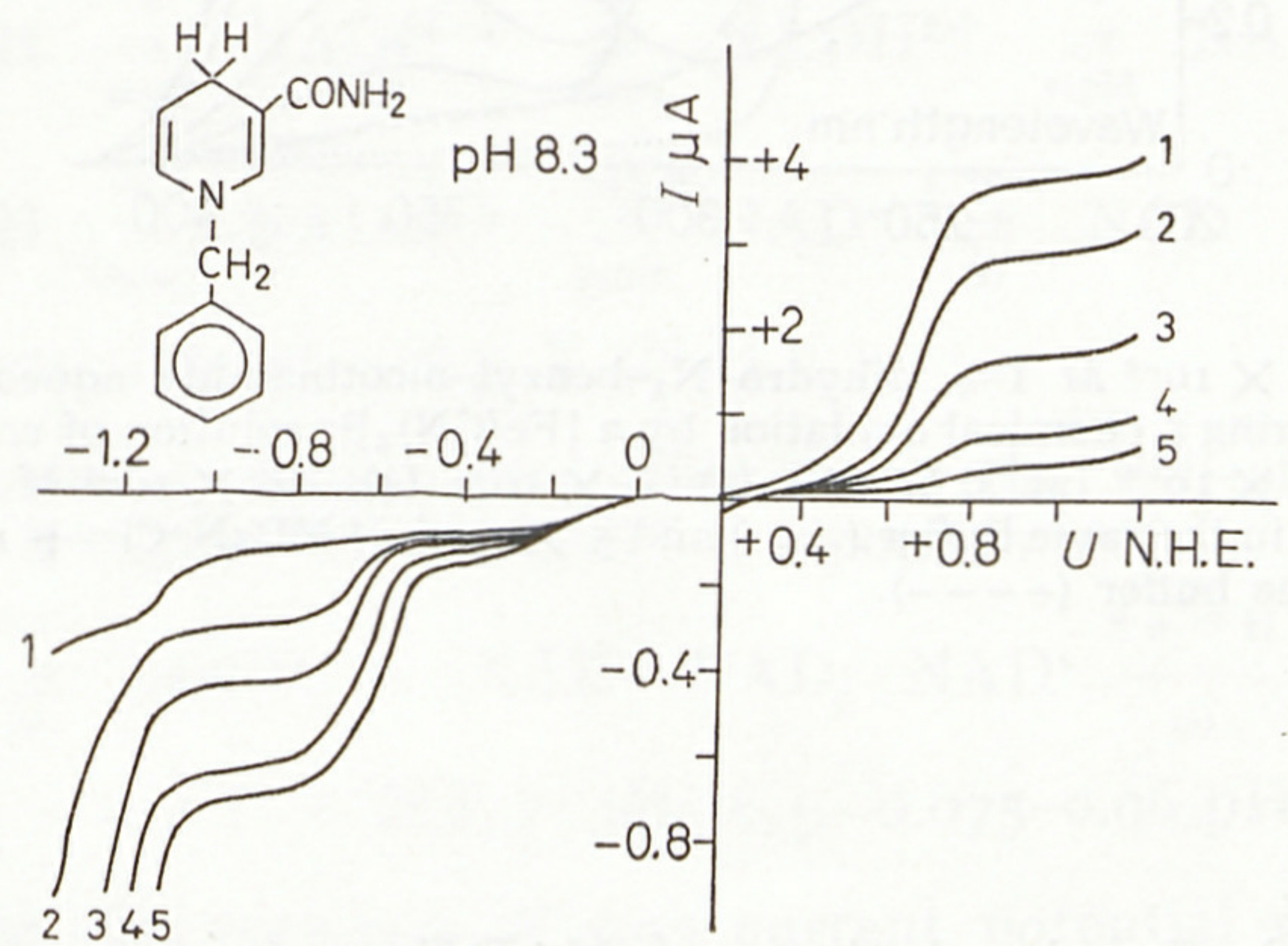

Fig. 4.

Current $v s$. potential curves of a $5 \times \mathrm{IO}^{-4} \mathrm{MI}-4$, dihydro- $\mathrm{N}_{1}$-benzyl-nicotinamide aqueous solution (buffered at $\mathrm{pH}$ 8.3) by voltammetry on a rotating Pt disk electrode (anodic part) and controlled drop-time polarography (cathodic part) during a macroscale electrolysis at +o.85 V (N.H.E.). Initial solution : curve (I), solution after 0.25 (2), 0.50 (3), I.o (4), and I.2 F/mole (5) electrolysis. 


\section{Chemical oxidation of $\mathrm{NBzNH}$}

Total chemical oxidations of $5 \times \mathrm{IO}^{-4} M \mathrm{NBzNH}$ solutions were performed by $\left[\mathrm{Fe}(\mathrm{CN})_{6}\right]^{3-}$ in borate and Tris buffers $(\mathrm{pH} 8.2)$ : the reaction is rapid and complete as checked by UV spectrophotometry and electrochemistry. The reaction product was identified as $\mathrm{NBzN}+$ through its polarographic patterns. As $\left[\mathrm{Fe}(\mathrm{CN})_{6}\right]^{4-}$ presents an important UV absorption in the $265 \mathrm{~nm}$ region, it is not possible to follow $\mathrm{NBzN}+$ concentration by this method: this was obtained by polarography.

The decrease of $\mathrm{NBzNH}$ concentration (followed by UV spectrophotometry at $355 \mathrm{~nm}$ (Fig. 5) and not by voltammetry, because of the interference with the $\left[\mathrm{Fe}(\mathrm{CN})_{6}\right]^{4-}$ oxidation) equals the increase of $\mathrm{NBzN}+$ concentration, both variations being proportional to the added quantity of $\left[\mathrm{Fe}(\mathrm{CN})_{6}\right]^{3-}$. In spite of numerous attempts to have reproducible results, the number of $\left[\mathrm{Fe}(\mathrm{CN})_{6}\right]^{3-}$ molecules necessary to oxidize one molecule of $\mathrm{NBzNH}$, varied from one experiment to another in the I.22.0 range.

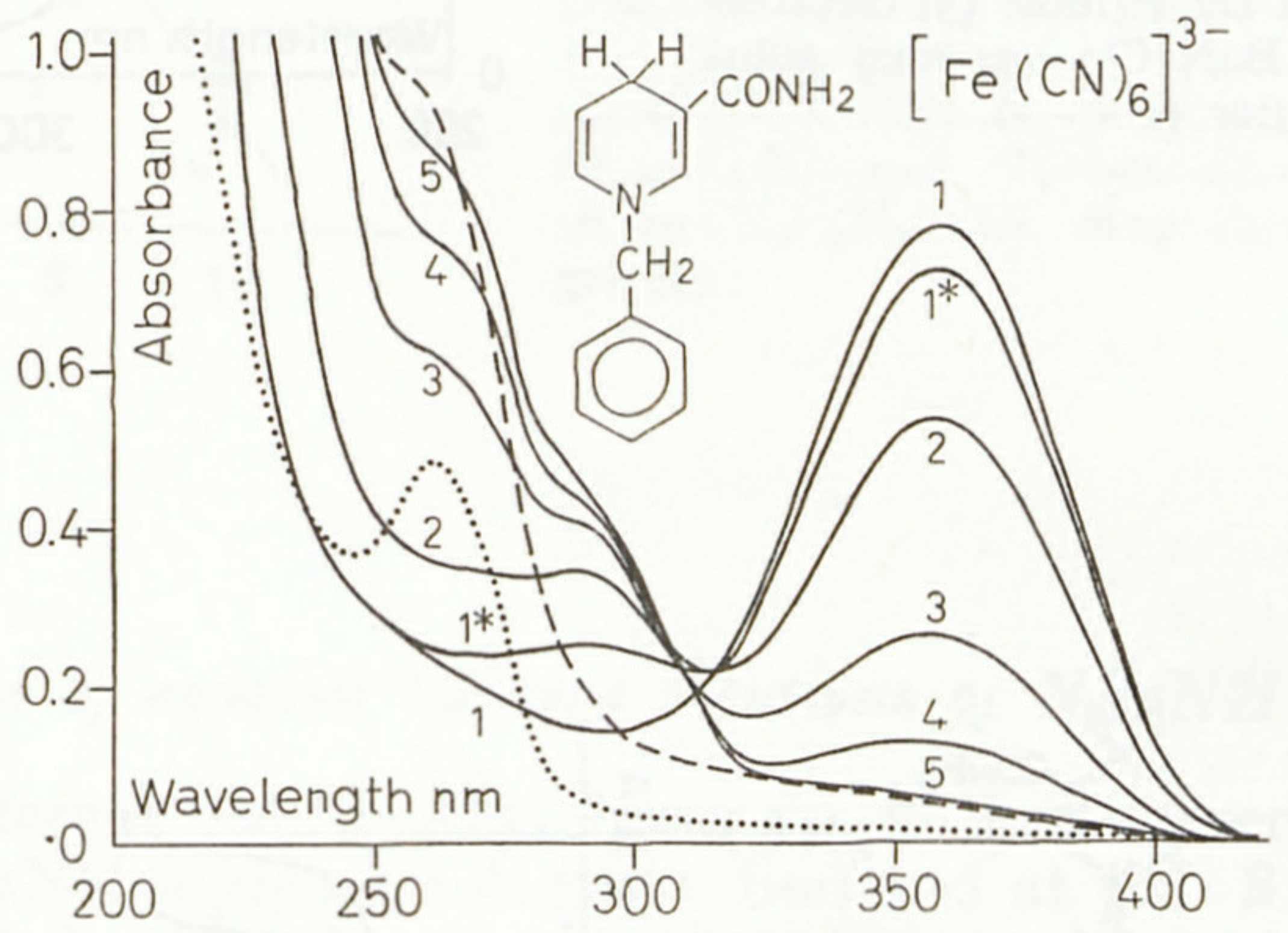

Fig. 5 .

UV spectra of a $5 \times$ IO $^{-4} M$ I-4, dihydro- $\mathrm{N}_{1}$-benzyl-nicotinamide aqueous solution (buffered at $\mathrm{pH}$ 8.3) during a chemical oxidation by a $\left[\mathrm{Fe}(\mathrm{CN})_{6}\right]^{3-}$ solution of concentration o (I), (I* after $24 \mathrm{~h}$ ), $2 \times \mathrm{IO}^{-4}(2), 6 \times \mathrm{IO}^{-4}$ (3), $8 \times \mathrm{IO}^{-4} \quad(4)$, Io $\times \mathrm{IO}^{-4} \mathrm{M} \quad(5) .5 \times \mathrm{IO}^{-4} \mathrm{M}$ $\mathrm{NBzN}+\mathrm{Cl}^{-}$solution in the same buffer $(\ldots$.$\left.) and 5 \times \mathrm{IO}^{-4} M \mathrm{NBzN}^{+} \mathrm{Cl}^{-}+\mathrm{IO}^{-3} \mathrm{M} \mathrm{Fe}(\mathrm{CN})_{8}\right]^{4-}$ solution in the same buffer $(----)$.

\section{Discussion}

Aqueous buffered solutions of $\mathrm{NADH}$ and of model compounds such as $\mathrm{I}-4$, dihydro- $\mathrm{N}_{1}$-propyl- and $\mathrm{N}_{1}$-benzyl-nicotinamide present a single 2 electron voltammetric wave on rotating $\mathrm{Pt}, \mathrm{Au}$ and glassy carbon disk electrodes. The registered half-wave potential is about $200 \mathrm{mV}$ smaller than the value obtained by HAAs ${ }^{10}$ and does not depend on $\mathrm{pH}$ in the $7.0-13.0$ range. 
Both macroelectrolysis at $+0.85 \mathrm{~V}$ (N.H.E.) and $\left[\mathrm{Fe}(\mathrm{CN})_{6}\right]^{3-}$ oxidation gives a total reaction from $\mathrm{NBzNH}$ to $\mathrm{NBzN}+$. HaAs obtained the same I00 \% yield with $\mathrm{NMeNH}$ and $\mathrm{NClBzNH}$ in basic acetonitrile ${ }^{9}$ and with $\mathrm{NADH}$ in a buffered aqueous solution at $\mathrm{pH}$ 8.6. ${ }^{10}$ Whereas, in all these experiments he found a $F / \mathrm{mol}$ ratio very close to 2 , we observed erratic values around 1.6 both by electrochemical and chemical oxidation. Obviously a side reaction occurs during these controlled oxidations, giving about $20 \%$ of the amount of $\mathrm{NBzN}+$. It cannot be related to a reaction with dissolved $\mathrm{O}_{2}$, for all experiments were conducted under $\mathrm{N}_{2}$ atmosphere. It cannot either be related to an oxidation by the buffer components (borate and Tris). Finally, this side reaction is not the saturation of the 5.6 bond of pyridine ring, happening at $\mathrm{pH} 7.0$, for the product of such a reaction is oxidizable on $\mathrm{Pt}$ only at I.07 V (N.H.E.) and can be detected spectrophotometrically at $290 \mathrm{~nm}$. Discussion is still open on the interpretation of these discrepancies which, to our knowledge, are not linked to experimental errors.

The results obtained during voltammetric oxidation of NADH and model compounds can be interpreted in terms of mechanism of reactions. The $\mathrm{pH}$-independence of the limiting current and of the half-wave potential shows that the energetics of possible acid-base reactions are not integrated in the redox ones. As cyclic voltammetry and ring-disk voltammetry experiments ${ }^{29}$ have clearly proved that within about $30 \mathrm{~ms}$ $\mathrm{NBzN}^{+}$is formed during $\mathrm{NBzNH}$ oxidation, a deprotonation should occur after a slow loss of electron and the overall mechanism should be controlled by the activation energy of the first electron departure. Thus, two mechanisms can be proposed for the electrochemical oxidation of $\mathrm{NADH}$ model compounds:

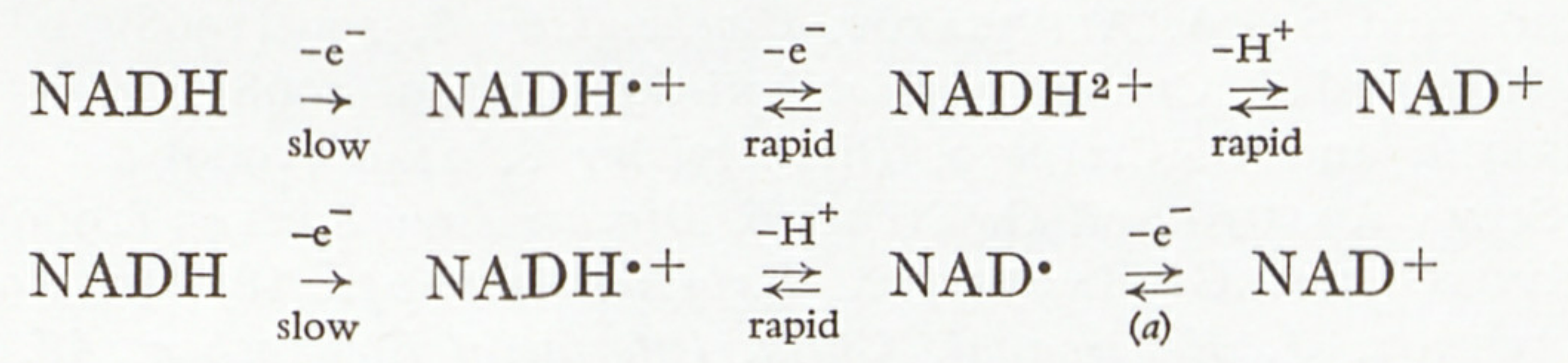

(a) reversible at $-0.7 \mathrm{~V}$ (N.H.E.)

These oxidation mechanisms differ from the two-step reduction mechanisms of $\mathrm{NAD}^{+3,5,30}$ and model compounds ${ }^{4,6,30}$

$$
\mathrm{NAD}^{+} \underset{(a)}{\stackrel{+\mathrm{e}^{-}}{\rightleftarrows}} \mathrm{NAD}^{\bullet} \rightarrow \mathrm{NAD}-\mathrm{NAD} ; \mathrm{NAD}^{\bullet} \underset{(b)}{\stackrel{+\mathrm{e}^{-}+\mathrm{H}^{+}}{\longrightarrow}} \mathrm{NADH}
$$

(a) reversible at $-0.7 \mathrm{~V}$ (N.H.E.) ; (b) at $\left(-0.075^{-0.06} \mathrm{pH}\right) \mathrm{V}$ (N.H.E.)

This means the nonsense of zero current potential measurements with NAD+-NADH system, if no mediator ${ }^{25,31}$ and even enzyme ${ }^{26}$ is added. It seems that most important energetical and mechanical informations could be gathered on this biological system by the study of the influence of these mediators and of the enzymatic functions on the electrochemical properties of both NAD+ and NADH. 


\section{References}

1 J.N. Burnett and A.L. Underwood, J. Org. Chem. 30, ir54 (r965)

2 J.N. Burnett and A.L. Underwood, Biochemistry 4, 2060 (I965)

3 H. Hanschmann, Thesis (Jena, D.D.R., I970)

4 D. Thévenot and G. Hammouya, Experientia Suppl. 18, 63I (I97I)

5 D. Thévenot and R. Buvet, J. Electroanal. Chem. Interfacial Electrochem. 39, 429 (I972)

6 D. Thévenot and R. Buvet, J. Electroanal. Chem. Interfacial Electrochem. 39, 447 (1972)

7 D. Thévenot and R. Buvet, J. Eectroanal. Chem. Interfacial Electrochem. 40, I97 (1972)

8 A.J. Cunningham and A.L. Underwood, Biochemistry 6, 266 (I967)

9 W.J. Blaedel and R.G. HaAs, Anal. Chem. 42, 9r 8 (r970)

10 R.G. HaAs, Thesis (Madison, Wisconsin, USA) r970, Diss. Abstr. 31B, r777 (I970)

11 P. Karrer, G. Schwarzenbach, F. Benz and U. Solmssen, Helv. Chim. Acta 19, 8I I (I936)

12 A.G. Anderson and G. Berkelhammer, J. Amer. Chem. Soc. 80, 992 (I958)

13 K. Wallenfels, D. Hofmann and H. Schüly, Justus Liebigs Ann. Chem. 621, I 88 (I958)

14 R. Segal and G. Stein, J. Chem. Soc. 1960, 254

15 A. Stock, E. Sann and G. Pelelderer, Justus Liebigs Ann. Chem. 621, I 88 (I959)

16 H. Diekmann, G. Englert and K. Wallenfels, Tetrahedron 20, 28I (I964)

17 S.G.A. Alivisatos, F. Ungar and G. Abraham, Nature 203, 973 (I964)

18 S.G.A. Alivisatos, F. Ungar and G. Abraham, Biochemistry 4, 26 i6 (i965)

19 K.S. Choi and S.G.A. Alivisatos, Biochemistry 7, igo (I968)

20 G.S.Y. KIM and S. Chaykin, Biochemistry 7, 2339 (I968)

21 S. Schreier and G. Cilento, Biochemistry 8, 2 I40 (I969)

22 M. da Silva Araujo and G. Cilento, Biochemistry 8, 2 I 45 (I969)

23 D. Thévenot and G. Hammouya, Experientia Suppl. 18, 647 (I97I)

24 D. Thévenot, J. Electroanal. Chem. Interfacial Electrochem. 46, 89 (I973)

25 S.J. Leach, J.H. Baxendale and M.G. Evans, Aust. J. Chem. 6, 395 (I953)

26 L. Rodkey, J. Biol. Chem. 213, 777 (I955)

27 W.J.M. Holman and C. Wiegand, Biochem. J. 43, 423 (I948)

28 C.H. Suelter and D.E. Metzler, Biochim. Biophys. Acta 44, 23 (I960)

29 P. LEDUC and D. ThÉvenot communication, Journées d'Electrochimie, Pau (I973)

30 K.S.V. Santhanam, C.O. Schmakel and P.J. Elving, Bioelectrochem. Bioenergetics 1, I47 (I974)

31 S. KwEE and H. LUnd, Bioelectrochem. Bioenergetics 1, 87 (r974) 